\title{
Single tree aboveground biomass models for native birch in Iceland
}

\author{
ThOrbergur HJalti JónSSON AND ARnór SnOrRason \\ Icelandic Forest Research, Mógilsá, 162 Reykjavik, Iceland \\ E-mail: thorbergur@skoguris (correspondingauthor),arnor@skoguris
}

\begin{abstract}
In Iceland, mountain birch dominates indigenous woodlands and scrub communities. For use in inventories of the natural birch population, we derived single parameter aboveground biomass functions from a stratified random sample encompassing the entire native birch population. We evaluated the accuracy of these models on independent data from the same population and used regressions of log-transformed predicted versus observed values and compared slope and intercept parameters against the 1:1 line. We propose that the level of accuracy of allometric models might be quantified by the size of Theil's random error component $\left(U_{\mathrm{e}}\right)$ and the normality of residual variances might be a decisive test of acceptable functions. The commonly used allometric power function without intercept proved highly accurate for diameters at ground level but was biased for diameters measured at $0.5 \mathrm{~m}$ up the stem. We compared both non-linear regressions and log-transformed linear regression techniques. The latter produced more accurate models especially for applications to small diameter trees. Power functions with intercept and diameters measured $0.5 \mathrm{~m}$ above ground produced accurate estimates, except for trees with diameters less than $50 \mathrm{~mm}$. We suggest allometric models for general use in Iceland for inventories of native birch woodlands and scrub.
\end{abstract}

Key words: allometric models, biomass, forest inventory, model evaluation

\section{YFIRLIT}

Lifmassaföll fyrir náttúrulegt birki á Íslandi

Á Íslandi er birki ríkjandi trjátegund í náttúrulegu skóg- og kjarrlendi. Við settum fram lífmassaföll fyrir birki sem byggja á lagskiptu slembiúrtaki úr öllum birkiskógum landsins. Við mátum áreiðanleika fallanna með öðru gagnasafni úr skógunum. Tekin var náttúrulegur lógarytmi af raungildum og spágildum og síðan fundið línulegt fall milli peirra. Skurðpunktur og halli línunnar var borinn saman við línu úr upphafspunkti með hallatölu einn. Við mátum skekkju í föllunum út frá hlutdeild tilviljanakenndra frávika af óskýrðum breytileika (Theil's $U_{\mathrm{e}}$ ) og normaldreifingu frávika. Einfalt veldisfall reyndist mjög áreiðanlegt pegar pvermál er mælt við jörðu en föll fyrir pvermál $0.5 \mathrm{~m}$ frá jörðu reyndust gefa skekkt gildi. Við bárum saman aðferðir með ólínulegu aðhvarfi lífmassa að pvermáli og línulegu aðhvarfi náttúrulegs lógaritma að pvermáli. Seinni aðferðin reyndist gefa betri spálíkön einkum fyrir grennri tré. Veldisföll með upphafsfasta sem felld eru að pvermáli $0,5 \mathrm{~m}$ yfir jörðu reyndust óskekkt fyrir tré með sverari en $50 \mathrm{~mm}$ stofn í $0,5 \mathrm{~m}$ hæð. Að lokum bentum við á bestu föllin til að áætla lífmassa ofanjarðar í úttektum á Íslenskum birkiskógum.

\section{INTRODUCTION}

Direct measurements of biomass are costly and usually destructive to the subject trees. Hence, allometric models are used to obtain biomass estimates from easily and non-destructively measured parameters such as stem diameters. For a long time, a single parameter power model 
of stem diameter (Equation 1) has been the preferred choice in biomass allometry (Litton \& Kauffman 2008, Mascaro et al. 2014, Niklas 2006) and commonly used in estimation of timber volume (Philip 1983):

$$
m=b d^{c}
$$

where $m$ is the biomass, $d$ the diameter and $b$ and $c$ are regression coefficients.

A priori, the above single parameter power model is only valid and unbiased for diameters measured at ground level $\left(d_{0}\right)$. The source of bias, for any measuring position further up the stem, is the mass of small trees with zero diameters at the set height of measurement. Due to the power-law relationships between diameters and biomass, the resultant overestimation may be trivial for large diameter trees, whereas for trees of small diameters, bias can be excessive (Mascaro et al. 2011).

Inherent bias due to the elevated position of diameter measurements might be eliminated by introducing an intercept term to the power expression (coefficient $a$ in Equation 2):

$$
m=a+b d^{c}
$$

The value of that intercept would become the average biomass of trees just short of attaining the set height of diameter measurements. However, for still smaller trees an allometric model based on ground level diameters is essential, but in that case without intercept.

It has been common practice to use logtransformation to linearize the single parameter power function (Equation 1) and fit that model to data by linear regression (Litton \& Kaufman 2008, Mascaro et al. 2011). A linear model fitted on log transformed data will, without adjustment of the intercept, yield biased predictions; for a given value of $\mathrm{X}$ the model would predict the median of Y rather than the mean. Baskerville (1972) proposed a correction factor for back transformation of log-transformed allometric power-law functions yielding mean value estimates. According to Niklas (2006) log-transformation of biomass data does not necessarily provide a better fit of data to a regression model compared to nonlinear regressions of untransformed data, but Mascaro et al. (2011) claim the opposite.

In Iceland, mountain birch (Betula pubescens Ehrh. var. pumila (L.) Govaerts) (Govaerts \& Frodin 1998) dominates indigenous woodlands and scrub communities (Kristinsson 1992) currently covering 150.6 kha (Snorrason et al. 2016). In natural stands, birch trees are more often polycormic, with stems of low stature and small diameters that are commonly leaning, contorted or procumbent, fluted in cross section, and variably twisted and swollen at the base (Jónsson 2004).

Low stature and high structural variability are challenging for allometry. Conventionally, stem diameter is measured at breast height, $1.3 \mathrm{~m}$ (Philip 1983). In Icelandic birch that position might be high up in the tree crowns and in many cases above the tree tops. Therefore, diameters of birch stems are usually measured at 0.5 meters $\left(d_{0.5}\right)$, knee-height (Jónsson 2004, Snorrason and Einarsson 2006, Hunziker et al. 2014). Consequently, biomass models from abroad based on breast height diameters are neither comparable nor useful.

Estimated stem basal areas are sensitive to methods by which cross sections are measured, e.g. diameters measured by calliper or derived from girth tape are not equivalent (Philip 1983). Therefore, it might prove more accurate and facilitate versatility to fit biomass models to true basal area and derive conversion factors for different practices of diameter measurement.

Two parameter models, including both diameter and tree height, might prove more accurate than single parameter models, but at the cost of efficiency (Philip 1983). The vertical height or length of variably leaning, contorted or procumbent stems of Icelandic birch is difficult and tedious to measure or even standardise. In Iceland, Snorrason and Einarsson (2006) published a two-parameter biomass function of diameter at knee-height and stem length for plantation grown birch and rowan (Sorbus aucuparia L.) combined, but stem length added insignificantly to model fit. For natural birch, 
adding stem length to biomass functions would result in considerably more costly fieldwork.

In Iceland, biomass functions of verified accuracy and representative of the entire native birch population are required for inventories supporting national carbon stock accounts demanded by international agreements on climate change and subject to transnational auditing. Hunziger et al. (2014) published single parameter allometric biomass functions based on knee-height diameters for above and below ground biomass components of birch in South Iceland. They presented models derived both by log-transformation and non-linear procedures, concluding that the latter gave a better fit. However, the accuracy of these models outside of the limited sampling range is unknown.

Our objective was to derive accurate, versatile and efficient single parameter, single tree above ground biomass functions for use in inventories of natural birch woodlands and scrub and evaluate the accuracy of these models with independent data. For that purpose, we explored regression of predicted versus observed values and compared slope and intercept parameters against the 1:1 line in accordance with Piñeiro et al. (2008). We specifically evaluated bias in the commonly used single parameter allometric power model when applied to non-ground level diameters as well as accuracies of allometric models derived by log-transformations and nonlinear procedures. To facilitate versatility of the models, we based our models on true basal area and derived conversion factors between different procedures of diameter measurements as well as between wet mass and dry mass of whole trees.

\section{MATERIALS AND METHODS}

For regressions and evaluations, we used data of above ground biomass and diameters measured at ground level and $0.5 \mathrm{~m}$ above ground from: (1) a stratified random sample (Jónsson 2004) and (2) a systematic sample (Snorrason 2010). Both datasets are from independent national inventories conducted by the Icelandic Forest Research covering the entire native birch population in Iceland.

\section{Random sample}

A stratified random sample (Husch 1971, Philip 1983) of 300 birch trees was drawn from the total population of indigenous birch woodlands and scrub in Iceland, excluding all anthropogenic birch woods, both seeded and planted. Trees were measured and samples obtained in the dormant season from September 1987 to April 1988.

The demarcation of the population and stratification by canopy height classes was based on an inventory from 1972-1975 and subsequent amendments to woodland maps (Aradóttir et al. 2001, Aradóttir et al. 1995, Bjarnason et al. 1977, Jónsson 2004). Woodlands were classified into three canopy height classes, 0-2, 2-4 and 4-12 m, referred to as scrub, scrub-woodland, and forest sub-populations (Jónsson 2004). A total of 60, 90 and 150 sampling units were selected from the sub-populations, respectively, with equal probabilities within sub-populations (Jónsson 2004).

In the 1972-1975 inventory, the entire population was comprised of more than six hundred birch woodland units, each with a unique reference number, woodland area and borders defined and drawn on aerial photographs and projected optically on topographic maps (Snorrason 2016). Also, all woodland units were classified by canopy height as well as several stand and site characteristics (Bjarnason et al. 1977). Using the method of Philip (1983), sampling units were assigned by random numbers to woodland units with probabilities in proportion to the area by which each woodland unit contributed to the total sub-population area. Within a woodland unit sampling points were located by randomly chosen coordinates on woodland maps. At the predetermined coordinates, bearing and distance, in the range 0-30 $\mathrm{m}$, were selected by random numbers and defined the sampling point. The sampling tree was the closest tree to this point, defined as all stems in a cluster originating from a single root system, irrespective of stem sizes. Diameter measurements were recorded on each stem at ground level $\left(d_{0}\right)$ and $0.5 \mathrm{~m}$ distance up stem $\left(d_{0.5}\right)$. A single observation was recorded at each 
location, measured either with calliper (diameter in $\mathrm{mm}$ ) or tape measure (girth in $\mathrm{mm}$ ). The thickest stem, measured $0.5 \mathrm{~m}$ distance up stem, was cut flush to the ground. Stem length, to the tip of the tree, was assessed in two ways: (1) the straight-line distance from ground level, and (2) stem length, measured with tape (recorded to $0.01 \mathrm{~m}$ ) along the stem surface, from the root collar (Jónsson 2004).

The top of the tree and branches less than 50 $\mathrm{mm}$ in diameter were cut off the main stem at the $50 \mathrm{~mm}$ mark and weighed (precision $0.1 \mathrm{~kg}$ ). The tree top, or in exceptional cases an upper canopy branch, was selected for sub-sampling, weighed separately and then all twigs were cut off that branch at the $10 \mathrm{~mm}$ diameter point. The remaining pruned branch was reweighed (precision $0.1 \mathrm{~kg}$ ). A sample of three twigs was put in sealed and labelled polythene bags and stored refrigerated at $+4^{\circ} \mathrm{C}$ until laboratory analysis.

From all trees, stem discs approximately $20 \mathrm{~mm}$-thick, were cut at ground level and 0.5 $\mathrm{m}$ distance up the stem. Trees of lesser $d_{0}$ than $50 \mathrm{~mm}$ were weighed whole. In the case of $d_{0}$ greater than $50 \mathrm{~mm}$ the stem and branches were weighed separately. Sections of $0.5 \mathrm{~m}$ lengths were weighted in a sequence ending with the recorded length and weight of the terminal piece to $50 \mathrm{~mm}$ top diameter. The topmost section and stem discs were labelled and put separately in tightly sealed polythene bags and stored at $+4^{\circ} \mathrm{C}$ until processed at the laboratory.

In the laboratory, stem sections with upper diameter of $50 \mathrm{~mm}$ were removed from sealed polythene bags and weighed immediately for fresh mass (precision $0.1 \mathrm{~g}$ ) and the volume was determined by water displacement (xylometry).

For each twig sample, numbers of short shoots were recorded as well as tallies of long shoots by one-centimetre length classes and counts of buds on long shoots. Leaves, male catkins and female catkins were counted, detached and weighed separately. The remaining twig was weighted, long shoots cut off the sample twig and the remaining twig split in two samples at the $5 \mathrm{~mm}$ diameter marks. The resultant samples of (a) long shoots, (b) twigs to
$5 \mathrm{~mm}$ diameter and (c) twig section of $5 \mathrm{~mm}$ to $10 \mathrm{~mm}$ diameter were weighed.

Samples of leaves, catkins, shoots, twigs sections and xylometry stem segments were dried at $105^{\circ} \mathrm{C}$ for 24 hours or until no further weight loss was detected. The samples were allowed to cool in a desiccator and weighed.

From the sample results, we derived partitioning of dry mass and ratio of dry mass to wet mass and used these proportions together with wet mass measurements in the field to estimate total tree dry mass, with and without leaves.

Stem discs were cured and desiccated in two consecutive batches of isopropanol. First, stem discs were submerged in reused isopropanol from a previous batch for two weeks then transferred to $100 \%$ pure isopropanol for a further two weeks and afterward dried for a week in a warm ventilated place (about $23^{\circ} \mathrm{C}$ ). When dry the discs were planed to about one-centimetre thickness and sanded with progressively finer grade ending with grade 800 giving a polished surface and mounted in sequence on plywood boards, with permanent labels. On each disc two perpendicular straight lines were drawn through the pith, such that one traversed the greatest diameter. Discs were photocopied and using planimeter the surface area of disc perimeters measured on the photocopy.

\section{Systematic sample}

From 2005-2009, a systematic sample of 69 birch trees from natural stands throughout Iceland was obtained from the National Forest Inventory sampling grid (Snorrason 2010, Snorrason 2016). A systematic sample of permanent measuring plots was derived by laying a $1.5 \times 3.0 \mathrm{~km}$ grid on woodland maps covering the entire population of natural birch in Iceland. At each woodland overlapping grid, a circular $200 \mathrm{~m}^{2}$ sample plot was established. Tree diameters were recorded by sub-sampling at three levels within the plot: (1) trees of $d_{0.5}$ $100 \mathrm{~mm}$ or more reaching the forest canopy, recording tree height, stem length and $d_{0.5} ;(2)$ trees of less than $100 \mathrm{~mm} d_{0.5}$ but more than two $\mathrm{m}$ high, recording tree height, stem length 
and $d_{0}$ and $d_{0.5 ;}$ and (3) trees of lesser height than two m, recording a tally of birch stems. Also, a subjectively chosen tree of seemingly average size was chosen for measurements of height, stem length, $d_{0}$, and $d_{0.5}$. The three levels of sub-sampling were: (1) the entire circular $200 \mathrm{~m}^{2}$ sample plot, (2) concentric circular sample plot of $50 \mathrm{~m}^{2}$, and (3) one to three $4 \mathrm{~m}^{2}$ circle subplots at $4 \mathrm{~m}$ distance from the centre of the main plot, respectively. The procedure was described in detail in Snorrason (2010). Diameter measurements were by single calliper readings.

Trees in the permanent plot must remain intact for future measurements. Therefore, substitute stems were identified outside of the $200 \mathrm{~m}^{2}$ permanent sample plot, of similar size and growth habit to the measured candidate tree of less than two $\mathrm{m}$ height (in the 4- $\mathrm{m}^{2}$ sub-plots). The substitute tree was measured for the same variables as the corresponding candidate tree; cut flush to the ground, put in sealed and tagged paper bag, dried at $85^{\circ} \mathrm{C}$ in a ventilated oven and weighted with and without foliage. Stem discs were cut at ground level and $0.5 \mathrm{~m}$ up the stem. Tree age, mean and annual diameter growth were measured in a dendrochronology laboratory. Substitute stems for measurements of biomass were sampled in 2005-2009.

\section{Modelling}

We derived allometric biomass models and estimated conversion factors using data from the stratified random sample for both: (1) dry mass derived by sectioning and sub-sampling the trees followed by detailed measurements in the laboratory, and (2) total above ground wet mass measured in the field.

We used linear regressions, with intercept set to zero, of diameter corresponding to true cross section area $\left(d_{\mathrm{g}}\right)$ (in the $\mathrm{y}$-axis) on directly measured diameters (x-axis): (1) single measurement with calliper in the field $\left(d_{\mathrm{m}}\right)$, (2) diameter calculated from circumference obtained by tape measure in the field $\left(d_{\mathrm{u}}\right),(3)$ greatest diameter of a stem disk measured in the laboratory $\left(d_{\mathrm{b}}\right)$, and (4) average diameter derived from the four perpendicular radii from the pith to the bark surface with one axis aligned with the greatest diameter $\left(d_{\mathrm{r}}\right)$. Similarly, we used linear regressions, with intercept zero, of (1) above ground dry mass of tree without foliage from wet mass measured in the field $(\rho)$, (2) above ground dry mass of tree including leaves from wet mass measured in the field $(\rho F)$, and (3) above ground dry mass of tree without leaves from dry mass with leaves $(\rho \mathrm{D})$. Lines without intercept were fitted both to $d_{0}$ and $d_{0.5}$; the slope values defined the corresponding conversion factors.

We used regressions to fit power-law models, with and without intercept; $m=a+b d^{\mathrm{c}}$ and $m=$ $b d^{\mathrm{c}}$, respectively, where $m$ is the biomass, $d$ the diameter and $a, b, c$ are coefficients. The powerlaw model without intercept was fitted to total tree biomass and $d_{0}$ as well as $d_{0.5}$. The power function including an intercept was only fitted to total tree biomass without leaves and $d_{0.5}$.

All models were fitted to diameters corresponding to measured areas of stem cross sections $\left(d_{\mathrm{g}}\right)$ and we fitted the models both to (1) dry mass data derived by detailed sampling and laboratory measurements and (2) wet mass measured in the field (Table 1).

We employed two techniques to fit powerlaw functions without intercept to data of wet and dry biomass and diameters corresponding to observed true cross section area $\left(d_{\mathrm{g}}\right)$ from $d_{0}$ and $d_{0.5}$.

Firstly, we applied non-linear regression to fit the basic power model without intercept to diameter data (Equation 3):

$$
m=b d^{c}+\varepsilon
$$

where $m$ is the biomass, $d$ the diameter, $b$ and $c$ are regression coefficients and $\varepsilon$ is random error. Secondly, we employed log-transformation (ln, natural $\log$ ) to linearize the power-function and used linear regression of the log-transformed function (Equation 4a):

$$
\ln (m)=\ln (b)+c \ln (d)+\varepsilon
$$

where $m$ is the total above ground biomass of tree excluding leaves, $d$ the diameter 
Table 1. Model reference, formula fitted to data, diameter variable (position of diameter measurement), regression procedure used to fit data (stratified random sample) to model and formulae used in evaluation on independent sample (systematic sample).

\begin{tabular}{lllll}
\hline Model & Formulae & $\begin{array}{l}\text { Diameter } \\
\text { variable }\end{array}$ & Regression procedure & Evaluation formulae \\
\hline M1 & $m \mathrm{DM}=b d^{c}$ & $d_{0}$ & Non-linear & $m \mathrm{DM}=b d^{c}$ \\
$\mathrm{M} 2$ & $m \mathrm{DM}=b d^{c}$ & $d_{0}$ & Log-transformed linear & $m \mathrm{DM}=b d^{c}$ \\
M3 & $m \mathrm{DM}=b d^{c}$ & $d_{0.5}$ & Non-linear & $m \mathrm{DM}=b d^{c}$ \\
M4 & $m \mathrm{DM}=b d^{c}$ & $d_{0.5}$ & Log-transformed linear & $m \mathrm{DM}=b d^{c}$ \\
M5 & $m \mathrm{DM}-a \mathrm{DM}=b d^{c}$ & $d_{0.5}$ & Non-linear & $m \mathrm{DM}=a \mathrm{DM}+b d^{c}$ \\
M6 & $m \mathrm{DM}-a \mathrm{DM}=b d^{c}$ & $d_{0.5}$ & Log-transformed linear & $m \mathrm{DM}=a \mathrm{DM}+b d^{c}$ \\
M7 & $m \mathrm{WM}=b d^{c}$ & $d_{0}$ & Non-linear & $m \mathrm{DM}=\rho\left(b d^{c}\right)$ \\
M8 & $m \mathrm{WM}=b d^{c}$ & $d_{0}$ & Log-transformed linear & $m \mathrm{DM}=\rho\left(b d^{c}\right)$ \\
M9 & $m \mathrm{WM}=b d^{c}$ & $d_{0.5}$ & Non-linear & $m \mathrm{DM}=\rho\left(b d^{c}\right)$ \\
$\mathrm{M} 10$ & $m \mathrm{WM}=b d^{c}$ & $d_{0.5}$ & Log-transformed linear & $m \mathrm{DM}=\rho\left(b d^{c}\right)$ \\
$\mathrm{M} 11$ & $m \mathrm{WM}-a \mathrm{WM}=b d^{c}$ & $d_{0.5}$ & Non-linear & $m \mathrm{DM}=\rho\left(a \mathrm{WM}+b d^{c}\right)$ \\
$\mathrm{M} 12$ & $m \mathrm{WM}-a \mathrm{WM}=b d^{c}$ & $d_{0.5}$ & Log-transformed linear & $m \mathrm{DM}=\rho\left(a \mathrm{WM}+b d^{c}\right)$ \\
$h \mathrm{DM}$ & $m \mathrm{DM}=a h^{c}$ & $h$ & Log-transformed linear & None \\
$h \mathrm{WM}$ & $m \mathrm{WM}=a h^{c}$ & $h$ & Log-transformed linear & None \\
\hline
\end{tabular}

Legend: $m \mathrm{DM}$ : above ground dry mass of birch trees without foliage, $m \mathrm{WM}$ : above ground wet mass of birch trees without foliage measured in the field $(\mathrm{g} D \mathrm{DM}), \rho$ : conversion factor between wet mass and dry mass for total above ground biomass without leaves (currently evaluated, see text for details), $d_{0}$ : diameter of birch stems measured at ground level, $d_{0.5}$ : diameter birch stems measured $0.5 \mathrm{~m}$ up the stem, $h$ : Stem length measured from ground level along the stem surface to tree top (meters), $a \mathrm{DM}$ : coefficient $a$ (model M5, M6) estimated as $b 0.5^{\mathrm{c}}$ (coefficients $b$ and $c$ from formula $h \mathrm{DM}$ ) and $a \mathrm{WM}$ : coefficient $a$ (model M11, M12) estimated as $b 0.5^{\mathrm{c}}$ (coefficients $b$ and $c$ from formula $h \mathrm{WM}$ ).

measured either $d_{0}$ or $d_{0.5}, b$ and $c$ are regression coefficients, and $\varepsilon$ is regression error. Each line was then transformed back to a power function of the form (Equation 4b):

$$
m=e^{\left(\ln (b)+\frac{M S E}{2}\right)} d^{c}
$$

where MSE is the mean square error of the regression (regression error). The correction factor accounts for back-transformation of the regression error and is a requisite step in the use of linear models and log-transformed data in allometry (Baskerville 1972).

We composed power-law functions with intercept to $d_{0.5}$ (Equation 5):

$$
m=a+b d^{c}+\varepsilon
$$

Trees less than $0.5 \mathrm{~m}$ tall have no $d_{0.5}$ and cannot directly contribute to derivation of coefficient $a$. To derive a more accurate estimate of coefficient $a$, and making use of biomass information conveyed by trees less than $0.5 \mathrm{~m}$ tall, we estimated coefficient $a$ by fitting above ground biomass to measured stem length $(h)$ using linear regression and log-transformation (Equation 6):

$$
\ln (m)=\ln (b)+\mathrm{c} \ln (h)+\varepsilon
$$

As before, we transformed back the model with the method of Baskerville (1972):

$$
m=e^{\left(\ln (b)+\frac{M S E}{2}\right)} h^{c}
$$

and estimated biomass for a tree of $0.5 \mathrm{~m}$ stem length: 


$$
\mathrm{a}_{\mathrm{h}}=b 0.5^{c}
$$

We replaced coefficient $a$ in Equations 5 above with the estimated intercept $\left(a_{h}\right)$. We also subtracted the $a_{h}$-value from every biomass value $\left(m-a_{h}\right)$. We used both non-linear regressions to estimate the remaining coefficients $b$ and $c$ (Equation 3) and linear regression to fit a linearized power function by log-transformation to biomass values less than the $a_{h}$-value and corresponding $d_{0.5}$ :

$$
\ln \left(m-a_{h}\right)=\ln (b)+\mathrm{c} \ln (d)+\varepsilon
$$

As before, we transformed back the model using the method of Baskerville (1972). We then combined the intercept $\left(a_{h}\right)$ and the back transformed power-law models (without intercept).

For all models, we used the DurbinWatson statistic to indicate data independence and tested the normality of residuals by the Shapiro-Wilk-test, i.e. for a significant $p$-value if not normally distributed. Multiple linear regression and nonlinear estimation procedures of STATISTICA software with the loss function minimised by weighted least squares was used to fit the data to the respective regression models.

\section{Model evaluation}

In the systematic sample used for independent model evaluation, one diameter measurement was made by calliper at each measuring position. To adjust single diameter measurements by calliper to diameter derived from true basal area $\left(d_{\mathrm{g}}\right.$-value) applied in our biomass models we used a correction factor for $d_{\mathrm{m}}$ (Table 3 ). For evaluation, wet mass model estimates were converted to dry mass using the above-derived conversion factor $(m \mathrm{DM}=\rho \mathrm{mWM}$, where $m \mathrm{DM}$ is the dry mass, $\rho$ is the conversion factor (slope of a line without intercept for dry mass on wet mass of trees) and $m \mathrm{WM}$ is the wet mass, Table 1).

We compared biomass estimates from each model against independent dataset, i.e. not used in model regressions. Models derived by regressions employing the stratified random sample were compared to the independent systematic sample from the National Forest Inventory. Two models from Hunziker et al. (2014) of above ground biomass (functions for stems + branches)) were compared both to the systematic and to the stratified random samples.

In order to evaluate goodness of fit, we used regressions of observed biomass values from the independent sample (in the y-axis) on predicted values estimated from diameter measurements of that sample (in the $\mathrm{x}$-axis) as proposed by Piñeiro et al. (2008). We evaluated whether the slope and the y-intercept of the regression between observed and predicted values differed statistically from 1 and 0 , respectively.

We distinguished between different sources of predictive error by partitioning the squared sum of the predictive error (SSPE $=\Sigma_{n}\left(o b s_{i}-\right.$ pre $\left._{i}\right)^{2}$ ) by calculating Theil's partial inequality coefficients $(U)$ of bias $\left(U_{\text {bias }}\right)$, consistency $\left(U_{B-1}\right)$ and random error $\left(U_{\mathrm{e}}\right)$ (Smith \& Rose 1995) as described by Paruelo et al. (1988). The component $U_{\text {bias }}$ is the proportion of SSPE associated with mean differences between observed and predicted values (Equation 8):

$$
U_{\text {bias }}=\frac{n(O B S-P R E)^{2}}{S S P E}
$$

Consistency $\left(U_{\beta-1}\right)$ is the proportion associated with the slope $(\beta)$ of the fitted model and the 1:1 line defined by (Equation 9):

$$
U_{\beta=1}=\frac{(\beta-1)^{2} \sum_{n}\left(\text { pre }_{i}-P R E\right)^{2}}{\operatorname{SSPE}}
$$

Theil's component of random error $\left(U_{\mathrm{e}}\right)$ is the proportion associated with unexplained variance (Equation 10):

$$
U_{e}=\frac{\sum_{n}\left(e s t_{i}-o b s_{i}\right)^{2}}{S S P E}
$$

Where obs and pre are the observed (independent samples) and predicted values by biomass functions, respectively: $O B S$ and $P R E$ are the means of the observed and predicted values, respectively; est are the values estimated 
from the fitted regression model (observed biomass values from the independent sample on predicted values estimated from diameter measurements of that sample); and $n$ is the number of observations (for details see: Paruelo et al. 1988). By definition the sum of the three components is unity $\left(U_{\text {bias }}+U_{B-1}+U_{\mathrm{e}}=1\right)$.

Tests of statistical significance are subject to the standard assumptions underlying regressions; homogeneity of variance, normality, and independence (Smith and Rose 1995). Due to pervasive heteroscedasticity, we used logtransformation (ln, natural logarithm) of model estimates and independent data before applying linear regression to observed and predicted values in the independent dataset. Normality of residuals was tested by the Shapiro-Wilk-test, significant $p$-value if not normally distributed. Durbin-Watson statistic was used to indicate data independence. Biomass data compared was without foliage (biomass with foliage is not comparable for samples from unlike dates during the growing season).

Diameters recorded in the independents systematic sample were single measurements at ground level or $0.5 \mathrm{~m}$ up the stem, with calliper. Therefore, appropriate correction factor $\left(d_{\mathrm{m}} \rightarrow\right.$ $d_{\mathrm{g}}$ ) was used to estimate equivalent $d_{\mathrm{g}}$-values
(See Table 1 for overview of models evaluated).

\section{RESULTS}

The field crews excluded fifteen sampling positions from the intended stratified random sample of 300 sampling positions; two trees were in birch plantations, one tree was inaccessible and no birch was to be found at twelve sampling coordinates. One birch tree was added to the sample representing the biggest trees observed in natural woodlands and two trees had missing stem disks.

A total of 284 trees had complete records of diameters (Table 2) and wet mass measured in the field with average mass $16.9 \mathrm{~kg} \mathrm{WM}(\mathrm{kg}$ WM: kilograms wet mass, min: $0.1 \mathrm{~kg}$ WM, max: $410.6 \mathrm{~kg}$ WM). Trees with complete records of dry mass numbered 223 with average above ground dry mass of trees with and without foliage $11.4 \mathrm{~kg}$ DM (kg DM: kilograms dry mass, min: $0.027 \mathrm{~kg}$ DM, max: $228.0 \mathrm{~kg} \mathrm{DM})$ and $10.9 \mathrm{~kg}$ DM (min: $0.027 \mathrm{~kg}$ DM, max: 222.7 $\mathrm{kg}$ DM), respectively.

The systematic sample used for independent evaluation of regression models contained 65 and 69 valid cases of above ground dry mass without foliage and diameters measured at ground level and $0.5 \mathrm{~m}$ up the stem, respectively.

Table 2. Number of complete observations $(N)$ with mean, minimum and maximum values of diameter measured with calliper in the field $\left(d_{\mathrm{m}}\right)$, diameters derived from circumference measured in the field $\left(d_{\mathrm{u}}\right)$, maximum diameter measured on stem disc in the laboratory $\left(d_{\mathrm{b}}\right)$, average diameter derived from four perpendicular radii measured from the pith to the bark surface on stem discs in the laboratory $\left(d_{\mathrm{r}}\right)$, diameter derived from true surface area of stem discs measured in the laboratory $\left(d_{\mathrm{g}}\right)$, surface area of stem discs measured in the laboratory $(g)$ and a cross section shape ratio (deviation from perfect circle), measured at ground level $\left(d_{0}\right)$ and $0.5 \mathrm{~m}$ up $\operatorname{stem}\left(d_{0.5}\right)$.

\begin{tabular}{|c|c|c|c|c|c|c|c|c|c|}
\hline \multirow[t]{2}{*}{ Factor } & \multirow[t]{2}{*}{ Unit } & \multicolumn{4}{|c|}{$d_{0}$} & \multicolumn{4}{|c|}{$d_{0.5}$} \\
\hline & & $\mathbf{N}$ & Mean & Min & $\operatorname{Max}$ & $\mathbf{N}$ & Mean & Min & $\operatorname{Max}$ \\
\hline$d_{\mathrm{m}}$ & $\mathrm{mm}$ & 216 & 65 & 10 & 213 & 227 & 46 & 3 & 185 \\
\hline$d_{\mathrm{u}}$ & $m m$ & 57 & 139 & 57 & 323 & 51 & 121 & 52 & 283 \\
\hline$d_{\mathrm{b}}$ & $\mathrm{mm}$ & 276 & 79 & 9 & 321 & 274 & 57 & 3 & 289 \\
\hline$d_{\mathrm{r}}$ & $\mathrm{mm}$ & 265 & 72 & 9 & 255 & 264 & 54 & 3 & 265 \\
\hline$d_{\mathrm{g}}$ & $\mathrm{mm}$ & 284 & 73 & 9 & 294 & 279 & 55 & 4 & 267 \\
\hline$g^{*}$ & $\mathrm{~cm}^{2}$ & 284 & 58,4 & 0,6 & 676,9 & 280 & 35,8 & 0,1 & 557,9 \\
\hline
\end{tabular}

*Samples of two and six stem discs were missing from ground level and $0.5 \mathrm{~m}$ above ground, respectively. In some cases reliable diameter measurements were unobtainable due to fluting, buttresses, contorted stem form or wood rot. 
The average $d_{0}$ and $d_{0.5}$ were $18.2 \mathrm{~mm}(\min 5$ $\mathrm{mm}, \max 64 \mathrm{~mm})$ and $59.8 \mathrm{~mm}(\min 2, \max$ $214 \mathrm{~mm})$, respectively. Corresponding above ground mass measures were $0.27 \mathrm{~kg} \mathrm{DM}$ (min 0.002 and $\max 8.0 \mathrm{~kg} \mathrm{DM})$ and $13.1 \mathrm{~kg} \mathrm{DM}$ (min 0.025 and $\max 90.3 \mathrm{~kg} \mathrm{DM}$ ), respectively.

\section{Regressions}

Conversion factors to estimate diameters corresponding to true basal area $\left(d_{\mathrm{g}}\right)$ from a single measurement by calliper in the field $\left(d_{\mathrm{m}}\right)$, diameter derived from circumference assessed by tape measure in the field $\left(d_{\mathrm{u}}\right)$, maximum diameter of a stem section $\left(d_{\mathrm{b}}\right)$, average of maximum and diameter perpendicular to the maximum axis, both dissecting the pith $\left(d_{\mathrm{r}}\right)$ for measuring elevations at ground level $\left(d_{0}\right)$ and $0.5 \mathrm{~m}$ up stem $\left(d_{0.5}\right)$ explained most of the diameter $\left(d_{\mathrm{g}}\right)$ variation (Table 3 ). For whole trees, estimated average biomass conversion factors were $0.5372,\left(N=223\right.$, Adjusted $R^{2}=$ 0.9998, $P<0.001), 0.5552(N=223$, Adjusted $\left.R^{2}=0.9997, P<0.001\right)$, and $0.9675(N=223$, Adjusted $\left.R^{2}=0.9998, P<0.001\right)$ for estimation of (1) dry mass of tree without foliage from wet mass measured in the field, (2) dry mass of tree with leaves from wet mass measured in the field, and (3) dry mass of tree without leaves from dry mass with leaves, respectively (biomass in grams).

All regression models based on above ground dry mass (models M1 - M6) and wet mass (models M7 - M12) were highly significant $(F$-statistic, $p<0.0001)$ but all failed the Shapiro-Wilk normality test of residuals
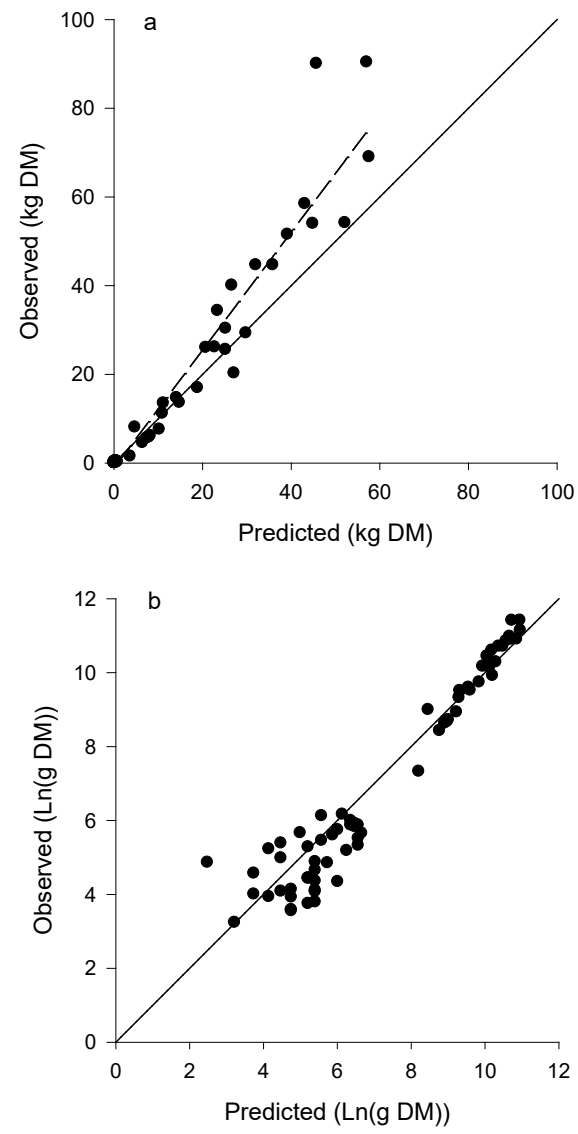

Figure 1. Observed by predicted values from model M4 of above ground biomass, untransformed (a) and log-transformed (b). Unbroken line indicates the 1:1 line of perfect conformity. Broken line (a), is a regression line fitted to untransformed data. Without logtransformation, Theil's partial inequality coefficients $U_{\text {bias }}, U_{\beta-1}$ and $U_{\mathrm{e}}$ were $0.0910,0.4362$ and 0.4728 , respectively. For log-transformation see Table 5.

Table 3. Conversion factors to estimate diameters corresponding to true basal area $\left(d_{\mathrm{g}}\right)$ from a single measurement by calliper in the field $\left(d_{\mathrm{m}}\right)$, diameter derived from circumference assessed by tape measure in the field $\left(d_{\mathrm{u}}\right)$, maximum diameter of a stem section $\left(d_{\mathrm{b}}\right)$, average of maximum and diameter perpendicular to the maximum axis, both dissecting the pith $\left(d_{\mathrm{r}}\right)$ for measuring elevations at ground level $\left(d_{0}\right)$ and $0.5 \mathrm{~m}$ up the stem $\left(d_{0.5}\right)$ with numbers of observations $(N)$ and adjusted coefficients of determination $\left(R^{2}\right)$.

\begin{tabular}{lccccccc}
\hline Diameter & \multicolumn{2}{c}{$\boldsymbol{d}_{\mathbf{0}}$} & & \multicolumn{2}{c}{$\boldsymbol{d}_{\mathbf{0 . 5}}$} \\
\cline { 2 - 4 }$(\mathbf{m m})$ & $\boldsymbol{N}$ & Conversion factor & Adjusted $\boldsymbol{R}^{\mathbf{2}}$ & & $\boldsymbol{N}$ & Conversion factor & Adjusted $\boldsymbol{R}^{\mathbf{2}}$ \\
\hline$d_{\mathrm{m}}$ & 214 & 0.9299 & 0.9880 & & 223 & 0.9346 & 0.9909 \\
$d_{\mathrm{u}}$ & 57 & 0.8917 & 0.9944 & & 51 & 0.8840 & 0.9960 \\
$d_{\mathrm{b}}$ & 275 & 0.9027 & 0.9960 & & 273 & 0.9373 & 0.9968 \\
$d_{\mathrm{r}}$ & 265 & 0.9880 & 0.9979 & & 264 & 0.9939 & 0.9991 \\
\hline
\end{tabular}


Table 4. Number of observations $(N)$, coefficient of determination $\left(R^{2}\right)$, estimated coefficients $b$ and $c$ with $p$-values within brackets, $F$-statistic with $p$-values and $z$-score of normality by Shapiro-Wilk-test with $p$-values of regressions defining models M1 - M12 (see Table 4 for details) and regressions of above ground dry mass $(h \mathrm{DM})$ and wet mass $(h \mathrm{WM})$ on stem length (see text for details).

\begin{tabular}{lcccccc}
\hline Model & $\boldsymbol{N}$ & $\boldsymbol{R}^{\mathbf{2}}$ & $\boldsymbol{b}$ & $\boldsymbol{c}$ & $\boldsymbol{F}$-statistic & Normality Z-score \\
\hline M1 & 223 & 0.9636 & $0.0535(p=0.0004)$ & $2.6450(p<0.0001)$ & $F_{2,222}=129.113, p<0.0001$ & $Z=9.5478, p<0.0001$ \\
M2 & 223 & 0.9133 & $0.0786(p<0.0001)$ & $2.5609(p<0.0001)$ & $F_{1,221}=2340.903, p<0.0001$ & $Z=5.7282, p<0.0001$ \\
M3 & 222 & 0.9620 & $0.1960(p<0.0001)$ & $2.4913(p<0.0001)$ & $F_{2,221}=131.696, p<0.0001$ & $Z=9.1777, p<0.0001$ \\
M4 & 222 & 0.8829 & $3.8631(p<0.0001)$ & $1.8146(p<0.0001)$ & $F_{1,220}=1667.983, p<0.0001$ & $Z=5.2257, p<0.0001$ \\
M5 & 222 & 0.9620 & $0.1928(p<0.0001)$ & $2.4943(p<0.0001)$ & $F_{2,221}=131.497, p<0.0001$ & $Z=9.5072, p<0.0001$ \\
M6 & 221 & 0.9040 & $0.0575(p<0.0001)$ & $2.6297(p<0.0001)$ & $F_{1,219}=2073.669, p<0.0001$ & $Z=6.5003, p<0.0001$ \\
M7 & 282 & 0.9325 & $0.1033(p<0.0001)$ & $2.6385(p<0.0001)$ & $F_{2,281}=159.431, p<0.0001$ & $Z=10.2277, p<0.0001$ \\
M8 & 282 & 0.9206 & $0.2382(p<0.0001)$ & $2.4583(p<0.0001)$ & $F_{1,280}=3261.009, p<0.0001$ & $Z=5.4513, p<0.0001$ \\
M9 & 278 & 0.9624 & $0.4011(p<0.0001)$ & $2.4735(p<0.0001)$ & $F_{2,277}=161.109, p<0.0001$ & $Z=9.8621, p<0.0001$ \\
M10 & 278 & 0.8800 & $0.5251(p<0.0001)$ & $1.7584(p<0.0001)$ & $F_{1,276}=2032.016, p<0.0001$ & $Z=4.3081, p<0.0001$ \\
M11 & 278 & 0.9624 & $0.3932(p<0.0001)$ & $2.4771(p<0.0001)$ & $F_{2,277}=160.812, p<0.0001$ & $Z=10.0883, p<0.0001$ \\
M12 & 282 & 0.8912 & $0.0662(p<0.0001)$ & $2.7638(p<0.0001)$ & $F_{1,280}=2303.389, p<0.0001$ & $Z=7.3995, p<0.0001$ \\
$h$ DM & 212 & 0,8638 & $0,0023(\mathrm{p}<0.0001)$ & $2.5124(p<0.0001)$ & $F_{1,210}=1339.445, p<0.0001$ & $Z=7.1424, p<0.0001$ \\
$h W M$ & 247 & 0,8657 & $0,0066(\mathrm{p}<0.0001)$ & $2,4423(p<0.0001)$ & $F_{1,245}=1586,469, p<0.0001$ & $Z=0,7132, p=0.2379$ \\
\hline
\end{tabular}

(normality test, $p<0.0001$, Table 4).

Variances increased strongly with tree sizes; therefore, we used log-transformation before regressing observed versus predicted values in model evaluations by independent samples. Without log-transformation few large trees exerted excessive leverage forcing the regression slope away from the 1:1 line (Figure 1a), i.e. erroneously inflating consistency value $\left(U_{\beta-1}\right)$ and supressing the random error component $\left(U_{\mathrm{e}}\right)$. With log-transformation of observed and predicted values, estimates were less variable but showed existing bias, e.g. underestimation of big trees by model M4 (Figure 1b, Table 5).

Evaluated on independent samples, power functions without intercept and $d_{0}$ (models M1, M2, M7, M8) had residual mean square variation almost entirely explained by random error (high $U_{\mathrm{e}}$-values, Table 5), indicating low bias, and all passed the normality test (Table 5). Visual inspections of plots of untransformed data (Figure 2a, models M1, M2), log-transformed residuals (Figure 2b, models M1, M2) and evaluations on independent data (Figure 2c, Models M1, M2) all indicated consistency and low bias (plots of models M7, M8 not shown). However, models fitted by log-transformed linear regressions (models M2, M8) had higher $U_{\mathrm{e}}$-values (less bias) compared to non-linear regressions (model M1, M7, Table 5). Thus, we conclude models M2 and M8 derived by logtransformed linear regression are accurate for inventories of native birch woodlands and scrub.

In all cases, power functions without intercept but with $d_{0.5}$ (models M3, M4, M9, M10) had comparatively low $U_{\mathrm{e}}$-values, indicating bias, and failed the Shapiro-Wilknormality-test (Table 5). By visual inspection of untransformed data, non-linear models seemingly produced accurate biomass estimates while log-transformed linear models progressively underestimated the biomass of trees of bigger sizes (Figure 2d, models M3, M4). Log-transformed residuals indicated biased estimates for smaller diameter trees from models derived by both regression procedures (Figure 2e, models M3, M4). Evaluated on independent sample, the non-linear model was highly biased for smaller size birches while the log-transformed regression models diverged less 

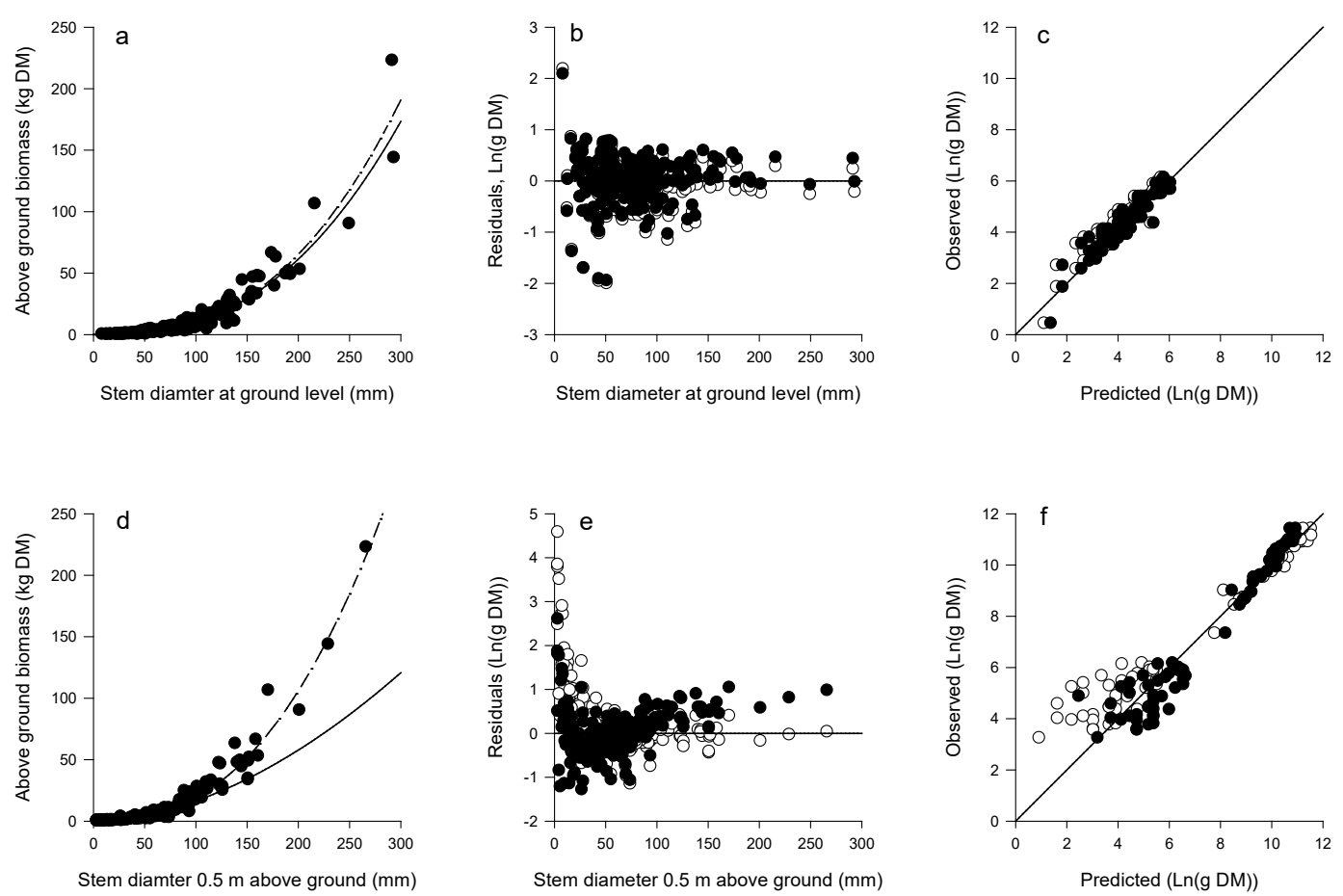

Figure 2. Allometric power functions without intercept fitted to above ground biomass (dry mass) of birch trees without foliage and stem $d_{0}\left(\mathrm{a}-\mathrm{c}\right.$, models M1, M2) and $d_{0.5}(\mathrm{~d}-\mathrm{f}$, models M3, M4). (a and d): Untransformed data; functions derived by non-linear regression (broken line, models M1, M3) and log-transformation and linear regression (unbroken line, models M2, M4). (b and e): Regression residuals (log-transformed); nonlinear regressions (o, models M1, M3) and log-transformed linear regressions (•, models M1, M3). (c and f): Observed biomass by predicted biomass for independent systematic sample; non-linear regressions ( $\mathrm{s}$, models M1, M3) and log-transformed linear regressions (•, models M1, M3). The 1:1 line through the origin is shown.

from the 1:1-line (Figure 2f, models M3, M4 and $U_{\mathrm{e}}$-values Table 5). Thus, both regression procedures produced inacceptable models for inventory use.

Hunziger et al. (2014) used non-linear procedures to counteract biases due to heteroscedasticity and suggested their models produced by non-linear regressions were superior to log-transformed linear models. Tested on two independent datasets their nonlinear biomass models (functions for stems + branches) produced low $U_{\mathrm{e}}$-values, indicating high bias, especially for small tree sizes (Figure $3 \mathrm{a}$ and $3 \mathrm{~b}$ ). On the other hand, their log-transformed regression models proved more accurate (Table 5, Figure $3 \mathrm{~d}$ and 3e). Our evaluations of two independent samples clearly showed the importance of such double checking in resolving methodological issues.

Hunziger et al. (2014) based their models on $d_{0.5}$ and irrespective of regression procedure failed the normality test (Table 5). Thus, all presently evaluated power functions without intercept but based on $d_{0.5}$ failed the normality test and proved biased. These results are consistent with the hypothesis that power-law models without intercept are only valid for diameters measured at ground level.

Regressions of above ground biomass (wet or dry mass without foliage) on stem length were highly significant ( $F$-statistic, $p<0.0001$, Table 4). Based on these functions, estimated biomass intercepts (coefficient $a$, Equation 2) were $42.5526 \mathrm{~g} \mathrm{DM}$ and $92.4779 \mathrm{~g} \mathrm{WM}$ for dry mass ( $a \mathrm{DM}$, models M5, M6) and wet mass ( $a \mathrm{WM}$, models M11, M12), respectively (Table 

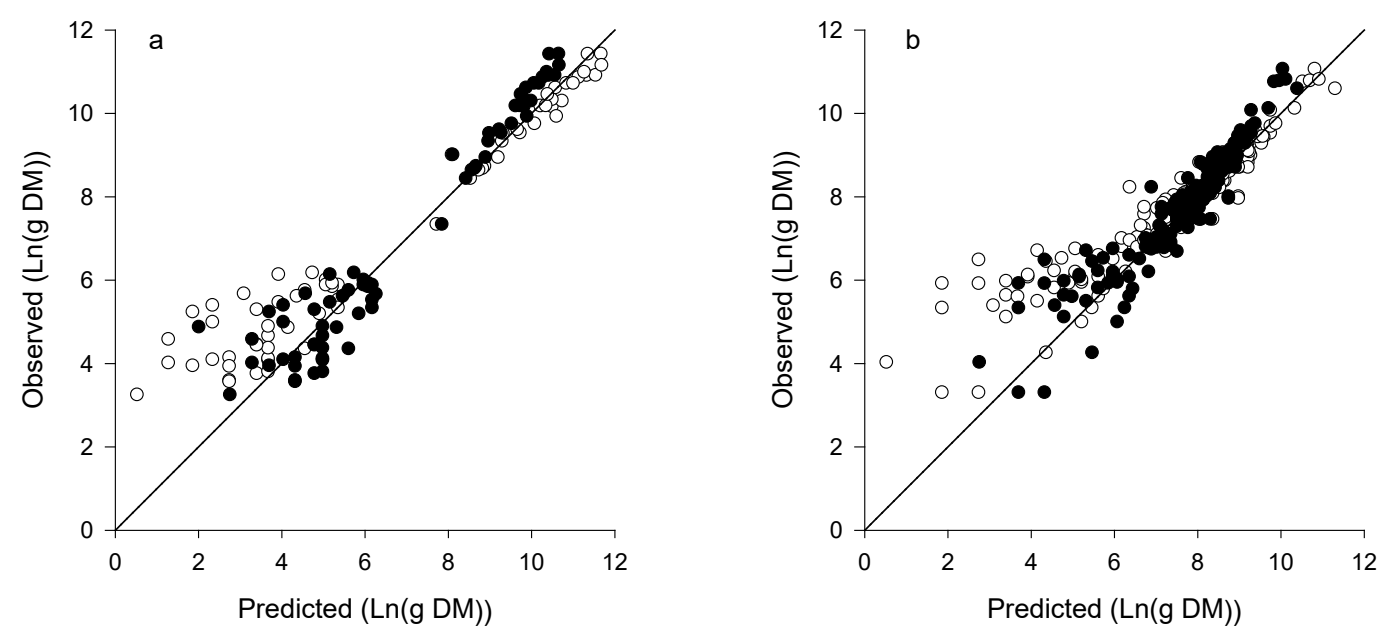

Figure 3. Log-transformed observed above ground biomass of birch trees without foliage plotted on log transformed predicted values from, (a) independent systematic sample and (b) stratified random sample from the entire native birch population. Non-linear regression models ( ) and log-transformed linear regressions $(\bullet)$ from Hunziker et al. (2014).

Table 5. Linear regression of observed (systematic sample) by predicted above ground biomass without foliage; estimated coefficients $a$ and $b$ with $p$-values within brackets, Durbin-Watson $d$-statistic, $z$ - score of normality by Shapiro-Wilk-test with $p$-values and assessed normality $p=0.05$ within brackets, number of observations $(N)$, coefficient of determination $\left(R^{2}\right)$, Theil's partial inequality coefficients of bias $\left(U_{\text {bias }}\right)$, consistency $\left(U_{\beta-1}\right)$ and random error $\left(U_{\mathrm{e}}\right)$ of models M1 - M12 (see Table 1 and the text for details) and models (stems + branches) from Hunziker et al. (2014) derived by non-linear procedures (Hunz1A) and log-transformed linear regressions (Hunz2A). Models Hunz1B and Hunz2B were fitted by non-linear procedures (Hunz1A) and log-transformed linear regressions and tested on stratified random sample from the entire birch population.

\begin{tabular}{lccccccccc}
\hline Model & $\mathbf{a}$ & $\mathbf{b}$ & $\mathbf{D W - d}$ & $\begin{array}{c}\text { Normality of residuals } \\
(\mathbf{p}=\mathbf{0 . 0 5} \text {, Z-score, p-value } \\
\text { (normality) }\end{array}$ & $\mathbf{N}$ & $\mathbf{R}^{2}$ & $\mathbf{U}_{\text {bias }}$ & $\mathbf{U}_{\boldsymbol{\beta}-1}$ & $\mathbf{U}_{\mathbf{e}}$ \\
\hline M1 & $0.6203(p=0.0013)$ & $0.9081(p<0.0001)$ & 2.22 & $Z=1.3269, p=0,0923$ (Normal) & 63 & 0.879 & 0.2748 & 0.0511 & 0.6742 \\
M2 & $0.3469(p=0.0819)$ & $0.9379(p<0.0001)$ & 2.22 & $Z=1.3269, p=0.0923$ (Normal) & 63 & 0.835 & 0.0418 & 0.0301 & 0.9281 \\
M3 & $2.0484(p<0.0001)$ & $0,7698(p<0.0001)$ & 1.50 & $Z=2.5537, p=0.0053$ (Not normal) & 69 & 0.931 & 0.2306 & 0.4225 & 0.3468 \\
M4 & $-0.6346(p=0.0201)$ & $1.0569(p<0.0001)$ & 1.50 & $Z=2.5537, p=0.0053$ (Not normal) & 69 & 0.931 & 0.0902 & 0.0345 & 0.8753 \\
M5 & $0.5288(p=0.0018)$ & $0.9333(p<0.0001)$ & 1.45 & $Z=1.1826, p=0.1185$ (Normal) & 69 & 0.964 & 0.0153 & 0.1215 & 0.8632 \\
M6 & $0.7349(p<0.0001)$ & $0.9677(p<0.0001)$ & 1.37 & $Z=-0.4251, p=0.6646$ (Normal) & 69 & 0.962 & 0.5049 & 0.0140 & 0.4811 \\
M7 & $0.4153(p=0.0218)$ & $0.9570(p<0.0001)$ & 2.20 & $Z=0.6363, p=0.2623$ (Normal) & 65 & 0.901 & 0.2536 & 0.0136 & 0.7328 \\
M8 & $-0.2406(p=0.2399)$ & $1.0272(p<0.0001)$ & 2.20 & $Z=0.6363, p=0.2623$ (Normal) & 65 & 0.901 & 0.0783 & 0.0059 & 0.9158 \\
M9 & $1.9839(p<0.0001)$ & $0.7754(p<0.0001)$ & 1.50 & $Z=2.5537, p=0.0053$ (Not normal) & 69 & 0.931 & 0.2133 & 0.4196 & 0.3670 \\
M10 & $2.1742(p<0.0001)$ & $1.0906(p<0.0001)$ & 1.50 & $Z=2.5537, p=0.0053$ (Not normal) & 69 & 0.931 & 0.9257 & 0.0064 & 0.0679 \\
M11 & $0.3570(p=0.0351)$ & $0.9494(p<0.0001)$ & 1.44 & $Z=1.1246, p=0.1304$ (Normal) & 69 & 0.965 & 0.0000 & 0.0727 & 0.9273 \\
M12 & $0.7913(p<0.0001)$ & $0.9496(p<0.0001)$ & 1.33 & $Z=-0.9462, p=0.8280$ (Normal) & 69 & 0.960 & 0.4175 & 0.0378 & 0.5447 \\
Hunz1A & $2.3758(p<0.0001)$ & $0.7330(p<0.0001)$ & 1.50 & $Z=2.5533, p=0.0053$ (Not normal) & 69 & 0.931 & 0.2604 & 0.4762 & 0.2635 \\
Hunz1B & $2.9426(p<0.0001)$ & $0.6523(p<0.0001)$ & 1.62 & $Z=3.1910, p=0.0007$ (Not normal) & 171 & 0.866 & 0.1558 & 0.5476 & 0.2965 \\
Hunz2A & $-0.0903(p=0.7181)$ & $1.0344(p<0.0001)$ & 1.50 & $Z=2.5533, p=0.0053$ (Not normal) & 69 & 0.931 & 0.0411 & 0.0143 & 0.9446 \\
Hunz2B & $0.7488(p=0.0006)$ & $0.9205(p<0.0001)$ & 1.62 & $Z=3.1978, p=0.0007$ (Not normal) & 171 & 0.866 & 0.0702 & 0.0430 & 0.8868 \\
\hline
\end{tabular}



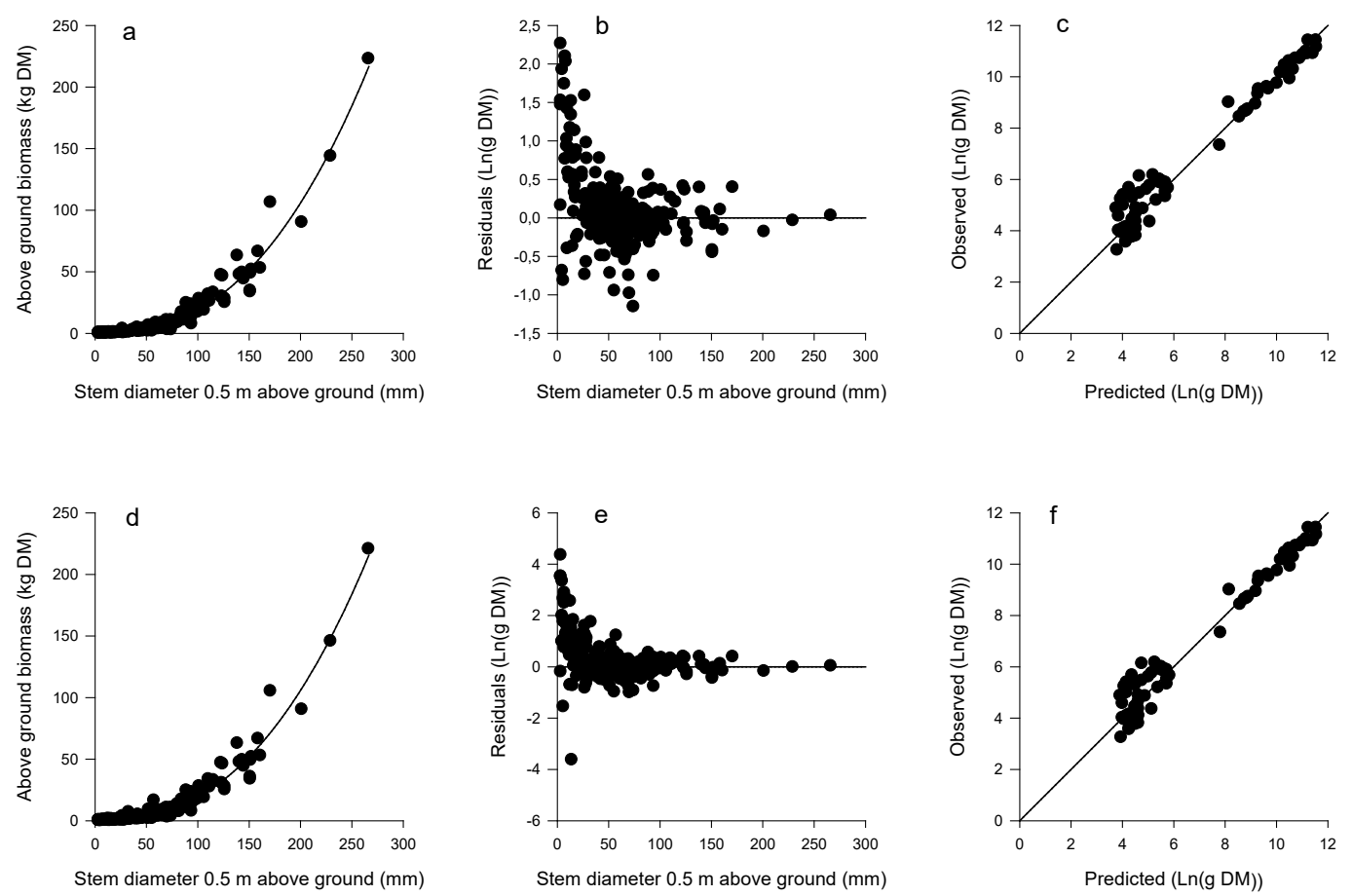

Figure 4. Above ground biomass without foliage by stem $d_{0.5}(\bullet)$. Model M5 derived from dry mass data $(\mathrm{a}-\mathrm{c})$ and model M11 based on biomass values derived by applying conversion factor to wet mass measured in the field ( $\mathrm{d}-\mathrm{e}$, see text for details). Fitted power function with intercept is shown by continuous curve (a and d). Residuals (log-transformed) of the fitted power function with intercept by stem $d_{0.5}$ ( $\mathrm{b}$ and e). Observed biomass by predicted biomass for independent systematic sample (c, model M5 and f, model M11). The 1:1 line through the origin is shown.

5). Allometric models derived by subtracting corresponding coefficient $a$-values from dry mass or wet mass data, then fitting allometric power functions (Equation 1) either by nonlinear or log-transformed linear regressions to the data, were all highly significant (Table 4). The composite power functions with intercept (Equation 2, models M5, M6, M11, M12) evaluated on independent data (systematic dataset) by regression of observed by predicted data all had normally distributed residuals (Table 5). The composite models M6 and M12 derived by log-transformed linear regressions were biased (low $U_{\mathrm{e}}$-values, Table 5), while models M5 and M11 fitted by non-linear procedures proved highly accurate (high $U_{\mathrm{e}}$-values, Table 5). Albeit the $a$-coefficient, visual inspections of log-transformed residuals indicated apparent bias for trees with diameters less than $50 \mathrm{~mm}$
(Figure 4b, model M5, Figure 4e, model M11). Even so, bias was not detected when compared to independent samples (Table 5, Figure 4c, model M5, Figure 4f, model M11).

Models derived from wet mass measured in the field and converted to dry mass by our presently constructed conversion factor proved equally or more precise than models based on dry mass data (Table 4 and 5). In all evaluations, the Durbin-Watson statistic indicated some but comparatively weak autocorrelation of the residuals (Table 5).

\section{DISCUSSION}

In biomass allometry, as well as in timber volume estimation, precision is desirable, whereas accuracy is of crucial importance (Philip 1983). Applied to inventory data, any bias in allometry will result in erroneous 
population means and totals. On the other hand, given a sufficiently large representative sample, biomass estimates derived from an unbiased model, albeit imprecise, would converge toward the true population mean. Therefore, usefulness of an allometric model is measured by its bias and efficiency (Philip 1983). Evaluation of bias must be done on independently collected representative samples, derived from the population to which the model is to be applied, and not on the data from which the model was originally constructed (Philip 1983).

A useful approach to evaluate models is to regress predicted versus observed values and compare slope and intercept parameters against the 1:1 line (Piñeiro et al. 2008). In that case, unexplained variation can be partitioned into components of bias $\left(U_{\text {bias }}\right)$, consistency $\left(U_{\beta-1}\right)$ and random error $\left(U_{\mathrm{e}}\right)$, referred to as Theil's partial inequality coefficients (Piñeiro et al. 2008, Smith \& Rose 1995). Both $U_{\text {bias }}$ and $U_{\beta-1}$ are different components of predictive bias, independent of and proportional to size, respectively. On the other hand, the component of random error $\left(U_{\mathrm{e}}\right)$ would not contribute to bias of estimates. The level of accuracy of allometric models might thus be quantified by the size of the random error component $\left(U_{\mathrm{e}}\right)$.

Regressions of predicted versus observed values with partition of unexplained variation is subject to the standard assumptions underlying regression being met; independence of residuals, homogeneity and normality of variances (Smith \& Rose 1995). By definition, our independent samples should pass the requirement of independence of residuals. Nevertheless, the Durbin-Watson statistic indicated weak autocorrelation of residuals, probably due to regional variation in tree sizes (c.f. Jónsson 2004) and data arranged in geographic sequence. In any case weak autocorrelation is of minor concern.

Heteroscedasticity of variances is pervasive in biomass data (Baskerville 1972, Mascaro et al. 2011). Log-transformation usually both linearizes the data and homogenizes variances (Mascaro et al. 2011). Without logtransformation, extreme observations have a large influence on the estimates of bias, slope and variance, as well as correlation (Smith \& Rose 1995). Therefore, log-transformation is necessary before regressing predicted on observed values and computing Theil's partial inequality coefficients.

In every case, the Shapiro-Wilk-normalitytest identified the inherently biased power-law model (without intercept) when applied to $d_{0.5}$. Therefore, normality of residual variances, in evaluation by linear regression of independent samples, might be a decisive test of acceptable models.

Our evaluation by two independent samples supports the procedure of Baskerville (1972) in deriving allometric models. Non-linear procedures, both without any correction for heteroscedasticity (our models) and correction procedures as applied by Hunziker et al. (2014), produced biased models. Therefore, non-linear methods should be avoided in biomass allometry unless the models are proven unbiased by rigorous testing on independent and representative samples.

Missing observations might not be random in relation to tree characteristics and thus compromise the representativeness of a random sample. The generally better performance of our models based on wet mass might be due to fewer missing observations as well as numbers of observations close to ideal (c.f. Roxburgh et al. 2015).

Allometric models are costly to construct and evaluate. In our present research, the detailed laboratory work was approximately five times more time consuming than the field work. The relationship between dry mass measured by detailed laboratory analysis and total tree wet mass measured in the field was both precise and accurate. There are thus opportunities by random and representative sub-sampling to economize on lab-work without compromising accuracy.

\section{CONCLUSIONS}

We emphasise that accuracy of allometric biomass functions should be evaluated on independent and representative samples from 
the population to which the model is intended to apply. That quality test might be achieved by regression of predicted versus observed values and comparison of slope and intercept parameters against the 1:1 line. Using that method, we propose that the level of accuracy of allometric models might be quantified by the size of the random error component $\left(U_{\mathrm{e}}\right)$ and normality of residual variances might be a decisive test of acceptable functions. Furthermore, we conclude that non-linear methods should be avoided in biomass allometry unless the functions have been proven unbiased by rigorous testing on independent and representative samples

The commonly used allometric power function, without intercept, proved highly accurate for $d_{0}$, but was biased for $d_{0.5}$. Power functions with intercept and $d_{0.5}$ produced accurate estimates except for trees with diameters less than $50 \mathrm{~mm}$. We propose our models M2 and M11 for general use in Iceland for inventories of native birch woodlands and scrub, the former for $d_{0}$ and the latter for $d_{0.5}$. To avoid bias, model M11 should only be used for diameters larger than $50 \mathrm{~mm}$.

\section{REFERENCES}

Aradottir AL, Thorsteinsson I \& Sigurdsson S 2001. Distribution and characteristics of birch woodlands in north Iceland. In: Wielgolaski FE (ed.) Nordic Mountain Birch Ecosystems. Partehenon Publishing, Paris, 51-61.

Aradottir AL, Thorsteinsson I \& Sigurdsson S 1995. Birkiskógar Íslands könnun 19871991 I. Yfirlit, aðferðir og niðurstöður fyrir Laugardalshrepp i Árnessýslu og Hálshrepp i Suður-Pingeyjarsýslu. [Survey of Icelandic birch woodlands 1987-1991. I. Overview, methods and results for Laugardalshreppur district in South Iceland and Hálshreppur district in North Iceland.] Rannsóknastöð Skógræktar ríkisins, Mógilsá, 64 p. [In Icelandic with English abstract].

Baskerville GL 1972. Use of logarithmic regression in the estimation of plant biomass. Canadian Journal of Forest Research 2, 49-53.

Bjarnason H, Sigurðsson S, \& Jörundarson H 1977. Skóglendi Íslands. Athuganir á stcerð pess $o g$ ástandi [Woodlands in Iceland, A survey of their extent and condition]. Skógrækt ríkisins og Skógræktarfélag Íslands, Reykjavík [In Icelandic].

Govaerts R \& Frodin DG 1998. World checklist and bibliography of Fagales (Betulaceae, Corylaceae, Fagaceae and Ticodendraceae). The Royal Botanical Gardens, Kew. 407 p.

Hunziker M, Siguroðsson BD, Halldórsson G, Schwanghart W \& Kuhn N 2014. Biomass allometries and coarse root biomass distribution of mountain birch in southern Iceland. Icelandic Agricultural Sciences 27, 111-125.

Jónsson TH 2004. Stature of Sub-arctic Birch in Relation to Growth Rate, Lifespan and Tree Form. Annals of Botany 94, 753-762.

https://doi.org/10.1093/aob/mch200

Kristinsson H 1995. Post-settlement history of Icelandic forests. Búvísindi 9, 31-35.

Litton CM \& Kauffman JB 2008. Allometric Models for Predicting Aboveground Biomass in Two Widespread Woody Plants in Hawaii. Biotropica 40, 313-320.

Mascaro J, Litton CM, Hughes FR, Uowolo A \& Schnitzer SA 2014. Is logarithmic transformation necessary in allometry? Ten, one-hundred, onethousand-times yes. Biological Journal of the Linnean Society 111, 230-233.

Mascaro J, Litton CM, Hughes FR, Uowolo A \& Schnitzer SA 2011. Minimizing Bias in Biomass Allometry: Model Selection and LogTransformation of Data. Biotropica 43, 649-653.

Niklas KJ 2006. A phyletic perspective on the allometry of plant biomass-partitioning patterns and functionally equivalent organ-categories. Tansley Review. New Phytologist 171, 27-40. https://doi.org/10.1111/j.1469-8137.2006.01760.x

Paruelo JM, Jobbágy EG, Sala OE, Lauenroth WK \& Burke, IC 1988. Functional and structural convergence of temperate grassland and shrubland ecosystems. Ecological Applications 8, 194-206.

Philip MS 1983. Measuring trees and forests. A textbook written for students in Africa. The Division of Forestry, University of Dar es Salaam, $338 \mathrm{p}$.

Piñeiro G, Perelman S, Guerschman JP \& Paruelo JM 2008. How to evaluate models: Observed vs. predicted or predicted vs. observed? Ecological Modelling 216, 316-322.

https://doi.org/10.1016/j.ecolmodel.2008.05.006 


\section{Roxburgh SH, Paul KI, Clifford D, England JR.}

\& Raison RJ 2015. Guidelines for constructing allometric models for the prediction of woody biomass: How many individuals to harvest? Ecosphere 6, 1-27.

http://dx.doi.org/10.1890/ES14-00251.1

Smith EP \& Rose KA 1995. Model goodness-of-fit analysis using regression and related techniques. Ecological Modelling 77, 49-64.

Snorrason A 2010. National Forest Inventories reports: Iceland. In: Tomppo E, Gschwantner T, Lawrence M \& McRoberts RE (eds.) National Forest Inventories - Pathways for common reporting. Springer, 277-289.

https://doi.org/10.1007/978-3-319-56201-8_16

Snorrason A 2016. Iceland. In: Vidal C, Alberdi I, Hernández L \& Redmond J (eds.) National Forest Inventories - Assessment of Wood Availability and Use. Springer, Switzerland, 451-465.

https://doi.org/10.1007/978-3-319-44015-6_24

Snorrason A \& Einarsson S F 2006. Single-tree biomass functions for eleven tree species used in Icelandic forestry. Icelandic Agricultural Sciences 19,15-24.

Snorrason A, Traustason B, Eggertsson Ó, Kjartansson BP, Heiðarsson L \& Ísleifsson R 2016. Náttúrulegt birki á Íslandi - ný úttekt á útbreiðslu pess og ástandi. [Natural birch woodland in Iceland - A new assessment on distribution and state]. Náttúrufraeðingurinn 86, 97-111. [In Icelandic with extended English summary and additional figure and table texts in English].

Received 25 June 2018 Acceped 8 November 2018 